Article

\title{
Digital Clients: An Example of People Production in Social Work
}

\author{
Elizabeth Martinell Barfoed \\ School of Social Work, Lund University, 22100 Lund, Sweden; E-Mail: elizabeth.martinell_barfoed@soch.lu.se
}

Submitted: 8 November 2018 | Accepted: 8 January 2019 | Published: 28 February 2018

\begin{abstract}
Digital work has become part of social workers' daily routines in countries where digitalisation is on the agenda. As a consequence, documentation practices are expanding-on paper as well as digitally-and include reporting detailed statistics about client interventions, filling in digital forms, and fulfilling local and national performance measurement goals. Standardised formulas with tick-box answers, fed into databases by the social worker, are examples of this digital endeavour. One example is the Addiction Severity Index (ASI), a questionnaire for estimating the client's life situation and needs, used in addiction care. However, difficulties in making the social workers use the results of the standardised questionnaire in social work investigations, where a storied form is traditionally preferred, have made social workers reluctant to use them. To encourage the use of the ASI, a software program was invented to transform the binary data from the questionnaire into a computerised storyline, imitating the storied form. The aim of this article is to describe the context of the digital storyline production and to analyse the particular type of "digital client" it creates. Possible consequences are discussed, such as the absent (or distorted) client voice. It is proposed that documentation systems, in whatever form, should not be regarded as neutral carriers of information, but must be analysed for how clients are (re)presented and, ultimately, how social work is consctructed.
\end{abstract}

\section{Keywords}

digital storytelling; digitalisation; documentation practices; narrative; people production; social work practice; standardisation

\section{Issue}

This article is part of the issue "'Producing People' in Documents and Meetings in Human Service Organizations", edited by Malin Åkerström (Lund University, Sweden) and Katarina Jacobsson (Lund University, Sweden).

(C) 2019 by the author; licensee Cogitatio (Lisbon, Portugal). This article is licensed under a Creative Commons Attribution 4.0 International License (CC BY).

\section{Introduction}

Digitalisation is changing how human service work is conducted. In Sweden, as well as in many other countries, a great deal of effort and high expectations is put into digitising social work. From national authorities, ideals like efficiency, quality and user participation are buzz words surrounding the digital endeavour (e.g., SALAR, 2019). Many professions in human service work, for example, doctors, nurses, teachers, and psychologists, are not only affected by, but deeply involved in, the digitalisation project. Social workers with administrative positions, often called controllers, a title borrowed from the economic sector, are employed to carry out 'digital accounting', instead of working with clients (cf. Martinell Barfoed, 2018).
Digital changes evoke reactions; one example is the introduction of decision-making robots in a few Swedish social services (and many more planned), for persons seeking economic support. On the one hand, this development has made skeptical social workers quit their jobs in protest. On the other hand, the robots are defended as less time-consuming (Svensson \& Larsson, 2017); providing time for better targeted client work-helping where help is needed. However, digital work, in general, has not been regarded as a time-saver: human service professionals, for example doctors, nurses, teachers, psychologists, and social workers, have voiced their concerns about less time spent with patients and clients and more time spent reporting statistics and filling in forms (examples regarding social work include: Abramowitz \& Zelnick, 2015; Baines, 2006; Gillingham, 2016; Gillingham \& 
Humphreys, 2010; Hjärpe, 2017; Lauri, 2016; White, Hall, \& Peckover, 2009; White, Wastell, Broadhurst, \& Hall, 2010).

Digital documentation systems have consequences at different levels. Skillmark (2018) argues that increased standardisation is a way for social workers to seek legitimacy as well as claiming jurisdiction, and hence, to increase professionalism. At the managerial level, guiding, controlling, and measuring how professionals perform their work are central features (Rogowski, 2011). However, the digital changes also have consequences for how the daily work is conducted, for example, how the interaction between the social worker and the clients unfolds, and how collaboration with colleagues and paperwork is organised (Jacobsson \& Martinell Barfoed, in press; Martinell Barfoed, 2018). Timmermans and Epstein (2010) noted that there are few empirical studies about the consequences of standardisation in the public sector and, therefore, propose an empirical bottomup approach to shed light on this phenomenon. This relative lack of empirically grounded research also includes digitalisation.

Based on a digitally produced paper-client used in the Swedish social services, the aim of the article is to reflect upon how clients in social work are constructed, when forms and questionnaires are part of everyday practice. The example sheds light on how a computer software program is transforming binary data from a standardised interview into a storyline. Thus, the data are modelled into a written story by the computer. The resulting story can be described as a "digital client". Prior (2003) has proposed that documents should be regarded as carriers: when analysing documentation systems, it is not sufficient to focus on the content-attention also needs to be given to the context of its production (Bowker \& Star, 1999; Prior, 2003). In this article, the context refers to the actions surrounding the standardised assessment tool Addiction Severity Index (ASI). More specifically, one of its parts, the "computerised" storyline, is analysed and some of the consequences are discussed.

\subsection{A Changing Professional Context}

The consequences and the challenges of the changes in welfare services have been addressed at length and, therefore, are only briefly mentioned here. The organisational changes brought about by New Public Management (Hood, 1995), including the outsourcing of welfare, privatisation, and fine-grained economic steering, are often proposed to explain this drive. Another explanation is the push for evidence-based human service work (Sackett et al., 1996). Digitalisation and standardisation tie in well with how the welfare state is currently guiding human service work. Quantification, or governing by numbers (Rose, 1991), is part of the changes in, for example, social work, where the national authorities are making professionals accountable for their work, resulting in monitoring and detailed guidance and reporting of how well the work is performed. This development is said to produce management bureaucracies (Hall, 2012), where local answers (statistic production, outcome reporting, etc.) to national questions ("How are you performing?"), take a lot of time.

Social workers have been rather reluctant to see the potential of the digital technology of a later date, for example, information communication systems (Devlieghere, 2017). While some are in favour of this digital development, others raise their concerns about a more bureaucratic and instrumental social work (e.g., Abramowitz \& Zelnick, 2015; Baines, 2006; Gillingham, 2016; Gillingham \& Humphreys, 2010; Hjärpe, 2017; Lauri, 2016; White et al., 2009). In an ethnographic childcare study in England and Wales, where the Integrated Children's System (ICS) was investigated, White et al. (2010) found that the social workers reported spending between $60 \%$ and $80 \%$ of their working time at the computer, not counting travelling time and meetings (confirmed by observations).

Whether social workers are reluctant with regards to digitalisation or not does not seem like the important question today-the digital information systems are spread in social work worldwide (e.g., Devlieghere, 2017; Gillingham, 2011; Munro, 2005; Parton, 2008). In Sweden, the first wave started in the late 1990s, where standardised assessment instruments like the ASI were introduced on a small scale, after cooperation between national authorities, implementation researchers and computer experts. Risk assessment tools and other digital decision-making templates and formulas then followed, many of them shaped after international models, but others being nationally constructed.

The second digital wave is still in the making. Today more comprehensive classification systems are introduced, with a wider scope. One example is The Classification of Health and Functioning (ICF), published by the World Health Organization in 2001 (a 276-pageslong catalogue of classifications), which is proposed to be used in varied settings (WHO, 2001). The use of the ICF has been studied in Swedish social work-it turned out to be difficult to adjust individual service user's needs to the fixed format of the ICF (Jacobsson \& Martinell Barfoed, in press, pp. 83-84). Achieving answers to the questions was not a straightforward process, but rather an interactional accomplishment. The attention lied heavily on the template, demonstrating the authority of the document (cf. Zimmerman, 2016).

In Sweden, digital tools and classification systems in use are often based on international models. Sometimes a slight adaption is needed; for example, a question about snuff (widely used in Sweden) in the ASI questionnaire, had to be slightly modified by the National Board of Health and Welfare. Locally constructed digital tools are also found in the "Methods guide", where social workers can pick and choose among existing digital decision-support tools (National Board of Health and Welfare, 2018). 
The changing professional context in social work not only has bearing on how social work is performed but also poses theoretical challenges. In an ethnographic study of social work in Australia, Gillingham (2016) found that standardised techniques shape the user and that the actions following the digital changes-digital reporting, extended paperwork, and standardised meetings over pre-formulated questionnaires-change how the social workers conduct their work and even think. By using a similar logic, we can presume that the professional tools and working methods utilised influence how the client is presented and constructed in investigations and case files. Hence, the form itself can be regarded as a carrier that transforms, in this case, social work practice (cf. Prior, 2003). Gillingham's conclusion can seem overly deterministic. Harold Garfinkel (1967a) ironically reminded us that people are not "dopes" and may act even under constraining structures. Research in social work demonstrates that creative strategies are used even when strict standardised routines are supposed to be followed. Björk (2016) noted how social workers act when conflicting interests arise between a standardised protocol and more acute client needs. The client is often found to have the upper hand when this occurs. In a study in England, similar strategies were used. The individual social worker sometimes added comments in a more narrative style in the margins of the standardised formulas they were filling in (White et al., 2009). The standardised form is sometimes presented as being easier to use, guiding the social worker with a fixed set of boxes to tick. However, a Swedish study found that it is not always possible to be "creatively professional". The standardised form is at times difficult to answer and the social worker and the client put a lot of effort into asking and answering the questions (Martinell Barfoed, 2018).

Lipsky (1980) called public administrators, like social workers, street-level bureaucrats, using their discretionary power when conducting their work, squeezed in between organisational and professional considerations. Bovens and Zouridis (2002) foresaw that the information and communication technology would turn the street-level bureaucrat into a system-level bureaucrat while handling the demands of (digital) information systems. They argued that three groups of employees would benefit from this development: (1) system designers and legal policy staff, (2) the managerial level; and (3) public information officers, informing and handling information and complaints. Similar tendencies may be observed in Swedish social work: In an ethnographic study in the social services, by Jacobsson and Martinell Barfoed (in press), new administrative positions, like controllers (with a social work degree) and data specialists, were found to be key players in the digital work conducted at the social services. In addition, they were often strategically placed close to the managerial level, thus giving a certain status to the new positions, compared to traditional social work.

\subsection{Producing People}

The analysis draws on two related theoretical perspectives. James A. Holstein's (1992) analytical framework has been helpful in showing how human service professionals are actively shaping and constructing their clients, or "producing people". Another theoretical viewpoint more specifically sheds light on how written forms and templates are influencing professional practice (e.g., Gillingham, 2016; Gillingham \& Humphreys, 2010; Gubrium, Buckholdt, \& Lynott, 1989; McLean \& Hoskin, 1998; White et al., 2009). Both perspectives are founded in the sociology of knowledge and social constructionism, where "facts" are not regarded as stable and definite, but instead are constructed or "worked up" at any given time and in any context (Berger \& Luckmann, 1966; Smith, 1974). In some empirical examples given in this article, constructing "out-there-ness" (Potter, 1997) is a way to handle the standardised formula. This can be done in different ways. One is to avoid embarrassing questions, by blaming them on the national authorities or an unknown producer. Another is, as we will see, to openly complain about a difficult or "strange" question during the interview; questions that can cause problems to both the interviewer and the interviewee (Martinell Barfoed, 2018).

Holstein expands on Yeheskel Hasenfeld's (1972) and Jeffrey M. Prottas's (1979) concept of people-processing. Hasenfeld and Prottas alike analyse and theorise on how people are processed in human service organisations and how this is accomplished: citizens becoming clients during this process (Prottas, 1979, p. 163). Holstein (1992) argues that people are not merely processed (passively), but rather they interact (actively) with the organisation and its representatives. Hence, the individual is not only processed within the constraints of a given institution but is actively constructed during this process. The individual does not have a fixed and stable identity when entering the institution; instead, identities are formed during the everyday actions and interactions taking place. Holstein stressed the importance of language in this production and proposed that the descriptions and narratives circulating in any professional discourse produce the client (Holstein, 1992). This "people production" is situated, that is performed during the daily activities at the institution. In the digital age, people production can be explored in different ways. In this article, some empirical examples are given to highlight and reflect upon a computerised digital story, which has entered Swedish social work in recent years.

When a document is empirically investigated, instead of finding an insignificant piece of paper, Prior (2003) finds a carrier with an impact on how professional practice is formed. For example, seemingly trivial and simple questions and answers cannot be taken out of context; the "facts and information" produced in social work are embedded in contextual factors, for example, complex life experiences, narratively arranged in personal 
stories, or written in notes and documents. After extensive ethnographic research in the USA, Gubrium et al. (1989), found that forms are highly influential in professional practice. Thus, completed forms are not simply a report of "what happened"; the report of any action is transformed when the form specifies what is to be filled in (White et al., 2009). McLean and Hoskin (1998) argue that forms and templates, instead of being objective, affect outcomes through their handling and the choices that are made when using them. They suggested that there are multiple influences involved in creating standards, with different agendas (cf. Bowker \& Star, 1999); however, this tends to be ignored and the instruments are thought to be objective. Lampland and Star (2009) have elaborated upon the tension between visibility and invisibility in standardisation. On the one hand, the standardised form is something highly material, with a fixed set of questions and answers, and step-by-step manuals guiding how to use them. On the other hand, the background of their production is obscured. Important choices, negotiations, disputes, and power plays among the persons involved, in the often tedious work creating them, are not known to the users - to them, the standard is presented as "a fact producing facts" (Lampland \& Star, 2009). The "plain-fact"-status and authority documents that are given in a public welfare agency often contrast with the skepticism the applicant's verbal claims are met with (Zimmerman, 2016). White et al. (2009) found that forms restrict social workers from providing more fluent descriptions; instead, the picture is restrained, and ambiguous and competing versions are suppressed. Gillingham (2016) even argued that standardised assessments "configure" the social worker and how the client is represented. At the same time, the circumstances of their production are often invisible. During fieldwork, it was found that neither the clients, nor the social workers, had knowledge of how the standard came about, as well as the work and negotiations behind them (Jacobsson \& Martinell Barfoed, in press).

Standardisation has a long history in society (Cicourel, 1964). Studies of standardisation-in-interaction (Maynard \& Schaeffer, 2006) analyse the performance of the standard, the actions and interactions of the parties involved. Critics have found that the rigidities of standardisation lead to awkward or even bizarre interactions (Cicourel, 1964; Houtkoop-Steenstra, 2000; Martinell Barfoed, 2018; Suchman \& Jordan, 1990). When standards on a large scale are introduced in social work it is important to study different aspects of how standardisation fits into their work, for example, how the standards are launched by national authorities (Jacobsson \& Martinell Barfoed, 2012).

One example of how children are "made and managed" in social work is given in an ethnographic study from England. Peckover, White and Hall (2010, s. 381) explored how an e-assessment system for children was implemented and found both technical and moral dimensions concerning its use. The technical issues included "the production of inaccurate data, poor searching techniques, and issues associated with accessing or using computers". In addition, moral dimensions were inherent; when information was shared by professionals in child welfare, judgements about what constituted a concern about a child, consent, security, and accountability, surfaced.

\section{Empirical Examples: Background}

In the article, standardised and digitised tools used by social workers in decision making are highlighted. The use of other important digital devices embedded in institutional organisations, such as social media, emails, and smartphones, are left out, even though they are also members of the digital family (cf. Svensson \& Larsson, 2017).

For this analysis I use empirical examples from a study on standardisation in social work as a point of departure; the examples were chosen because of their digital embeddedness. In the first example, a digital client story-"Data-Dennis" - is produced by a software program using binary data in a standardised form (ASI). In the research project, the standardised assessment form ASI was studied between 2010 and 2013. Participants were observed during 12 tape-recorded ASI interviews. The interviews were regarded as naturally occurring talk and as an interactive accomplishment (Garfinkel \& Sacks, 1986; for more detail see Martinell Barfoed, 2018). In addition, interviews with social workers, clients and computer system developers were conducted at probation offices and at the social services. In this research project "sitting-in" (Jacobsson, 2016) during the ASI interview gave important field notes, in addition to the taperecording of the interaction between the social worker and the client.

In the final part of the research project, digitalisation was changing social work in many ways, for example, private companies were offering digital support to social services. To understand more about the digital data support, qualitative interviews were conducted with two IT-workers, owners of a company licensed to handle the ASI-data from the local authorities (Martinell Barfoed, 2018). During the interviews, conducted by a colleague and me, the computer workers gave an example of a digital innovation: a software program transforming the binary data from the ASI interview into a digital storyline. At first, we thought the fictitious written document given to us, named "Dennis", was an example of what the computer could do. A couple of years later, it turns out that most Swedish local authorities use this software program (as per a telephone contact with IT worker 2, December 2018). Therefore, it is interesting to reflect upon this rather reversed way of handling client data (and clients) in social work: on the basis of the questionnaire data, the software program turns binary codes into a narrative for the social worker to copy into the investigation. To better understand the data that Dennis's story is built 
upon, an empirical example from one of the interviews in the ASI-project is given. The example is chosen to match Dennis's storyline. We begin with a short description of the ASI.

\subsection{The ASI: A Digital Tool}

The ASI is called a standardised assessment "instrument" and it is well-known globally (McLellan, Cacciola, Alterman, Rikoon, \& Carise, 2006). In Sweden, $70 \%$ of the clients in addiction treatment within the social services have been subject to the ASI interview (Lundgren et al., 2012). Originally, the ASI was designed for measuring the effects of alcohol and drug use, starting in the mid-1960s, and first aimed at Vietnam veterans in voluntary care (McLellan et al., 2006).

The ASI consists of four different parts: (1) a basic ASI interview between a social worker and a client, (2) a follow-up interview between a social worker and a client, (3) reporting the data to a database (social worker), and (4) transforming the binary data into a storyline (computer). The basic interview is a questionnaire consisting of 180 questions. In a personal interview, the social worker asks the questions and the client answers. The aim is to investigate and measure addiction habits and identify needs and risks. A given set of life areas are worked through, in the following order: (1) physical health, (2) work and income, (3) alcohol use, (4) drug use, (5) family and socialising, (6) problems with the law, and (7) mental health issues (National Board of Health and Welfare, 2014). Most questions are answered with "yesses" and "nos" in "tick-boxes". The problems are then graded by the client as well as the social worker. The social worker then chooses the final gradings in the different life areas. The second part of the ASI, a shorter follow-up interview, is conducted six to eight months after the basic interview. As the aim of the ASI is to measure drug habits and life situation, the second interview is important as a point of reference. However, this followup interview has turned out to be difficult to accomplish. When the laboratory logic of the ASI meets the logic of care, the latter often has the upper hand (Björk, 2016). The social worker has to adapt to the client and acute situations must be solved. The ASI-questionnaire becomes a second priority when, for example a client is hospitalised or homeless. Therefore, lower usage of the followup interview is reported (Björk, 2016).Björk, 2016 In the third part of the ASI, the data produced from the interviews are reported to a national database, managed by a private company, where the Swedish local authorities have paid access to different support tools. Finally, the fourth step is when the computer, after the social worker has entered the binary data by using a software program, transforms the results from the ASI interview into a computerised storyline.

The ASI is supposed to provide different answers, such as individual needs of care, data at an organisational level, and aggregated data at a national level. The data can also, after obtaining written permission from the local authorities, be used for research (National Board of Health and Welfare, 2014). The ASI is an example of the "multifunctionality" of the digital tools entering public service organisations (Mäkitalo \& Säljö, 2002). In a Swedish study of a categorisation system for the unemployed, Mäkitalo and Säljö (2002) find that categorisation serves diverse functions at different levels. The needs of the individual client, organisational demands, statistics to be filled out, etc. Different agendas were linked to the different actors involved. The professionals were well aware of this complexity, and therefore, when the clients were categorised into fixed categories, they were reflexively juggling the diverse demands and the consequences of their choice of category. The authors conclude that categorisation practices are hidden, that is, not visible to the public, but that they are still central features when social facts are produced.

\section{Analysis and Discussion}

In this part, two empirical examples are presented and analysed to illustrate the consequences of the digitised documentation practices. First, a short background about the design of the computer-generated narrative is given. Second, a computer-generated narrative is presented, analysed, and discussed. Third, interactional data from an ASI interview shows how the question and answer-interaction unfolds to shed light on what kind of data the computer-generated narrative is built upon.

\subsection{A Computer-Generated Narrative Is Designed}

An early problem, which initially gave the Swedish national authorities launching the ASI difficulties, was to motivate social workers to use the results from the ASI interview in their investigations. The results, given in binary codes (1s and 0s), were difficult to use in the narratively structured investigation, therefore social workers were somewhat reluctant in feeding the data into the ASI-database (Björk, 2016). Traditionally, the story has had a strong hold in social work discourse (cf. Hall, 1997). It turned out that the figures did not match the investigation format and the social workers in this sense had "good reasons" for "bad practice". (cf. Garfinkel, 1967b) The problem had to be addressed. A software program was designed, by two Swedish ASI-pioneers. The program turned the codes into a storyline, to meet the need for a more human-like narrative that better served the social work investigation. One of the computer developers explains in an interview:

The ASI interview itself is...you fill in $1 \mathrm{~s}$ and 0 s and so on. Then, in the ASI-net [a database where the results are fed in after the interview] you get a fluent narrative. So, if you fill in: "Man, 32 years old, Peter", the narrative will say: "Peter is 32 years old, and comes from Stockholm" etc., etc. (IT worker 1, May 2012) 
This computer-generated storyline was designed to make the use of the results of the ASI interview more attractive for the social workers. The colleague explains:

[The social workers] want to get this text compilation that they are using in the ongoing investigation. You know, there is always an investigation going on in Procapita or TreServa or The Umbrella, whatever it [the system] is called. And this text compilation has to be written. It must be part of the investigation, so....Today, the ASI-net [more exact, a particular program in this database] spits out a text, and they can almost momentarily "copy and paste" the story into the investigation. (IT worker 2, May 2012)

The computer-generated storyline is depicted in Figure 1. The figure demonstrates how the clients' personal "data" is "tick-boxed" into binary codes (1s and 0s) in the questionnaire and then ideally, as a second step, is fed into the ASI-net (National Board of Health and Welfare, 2014). Using the program developed by the Swedish computer system designers, the binary codes are transformed into a human-like narrative.

\subsection{Dennis: A Digital Client}

A fictitious example of a computer-generated storyline illustrates the story type that is produced by the computer. The prototypical example is Dennis, a 30-year-old-male, whose story was created in order to make the social workers more willing to feed the results into the ASI-net. Below, a part of the story is presented (the full story was two pages long). His personal "data" (that is, what he chooses to tell the social worker) is transformed into codes in a "tick-box" questionnaire. The social worker then feeds the figures into a specific database and the computer "spits out" the story. The "life area" in the following example from the ASI-questionnaire is called "Family and Socializing" (authors' translation). The computer narrates:
Dennis's marital status for 5 years is cohabiting. He is both satisfied and dissatisfied with this situation. He has lived with his partner and children for 5 years and is both pleased and displeased with this. They have children of their own. They are expecting a child. Dennis does not live with someone who abuses alcohol or drugs. He spends most of his spare time with family and loved ones who do not have current alcohol- or drug problems. He is happy to spend leisure time in this way.

The story is told in the third person perspective and the classic narrative is used as a format. However, the computerised narrative lacks the characteristics of human narration, which makes it appear rather awkward. The resulting narrative appears mechanical and seems impossible to copy-and-paste into the social work investigation without narrative editing (cf. Holstein \& Gubrium, 2000).

This short story is interesting in several ways. First, the language used by Data-Dennis is highly reminiscent of a bureaucratic discourse. The language is constructed to fit into a social work investigation, where impartiality and objectivity are central features (cf. Ponnert, 2015). However, it is rather difficult to understand what Dennis is trying to explain. A somewhat ambivalent discourse unfolds: "He is both satisfied and dissatisfied with this situation" and he "is both pleased and displeased with" his family life, gives a fragmented and confusing understanding of Dennis' family situation, and the story, in this unedited form, raises more questions than are being answered. As it stands, it is not possible to use in an ongoing investigation without changing the discourse. An anecdotal example gives an indication as to how social workers handle these narrative problems. While I was giving a lecture in the spring of 2015, an experienced social worker and ASI-user came forward and explained how he managed similar ambiguities: "You just change the text here and there, so it sounds more realistic", he explained. The example shows that creative strategies are needed to humanise the digital voice. A de-computerisation is needed

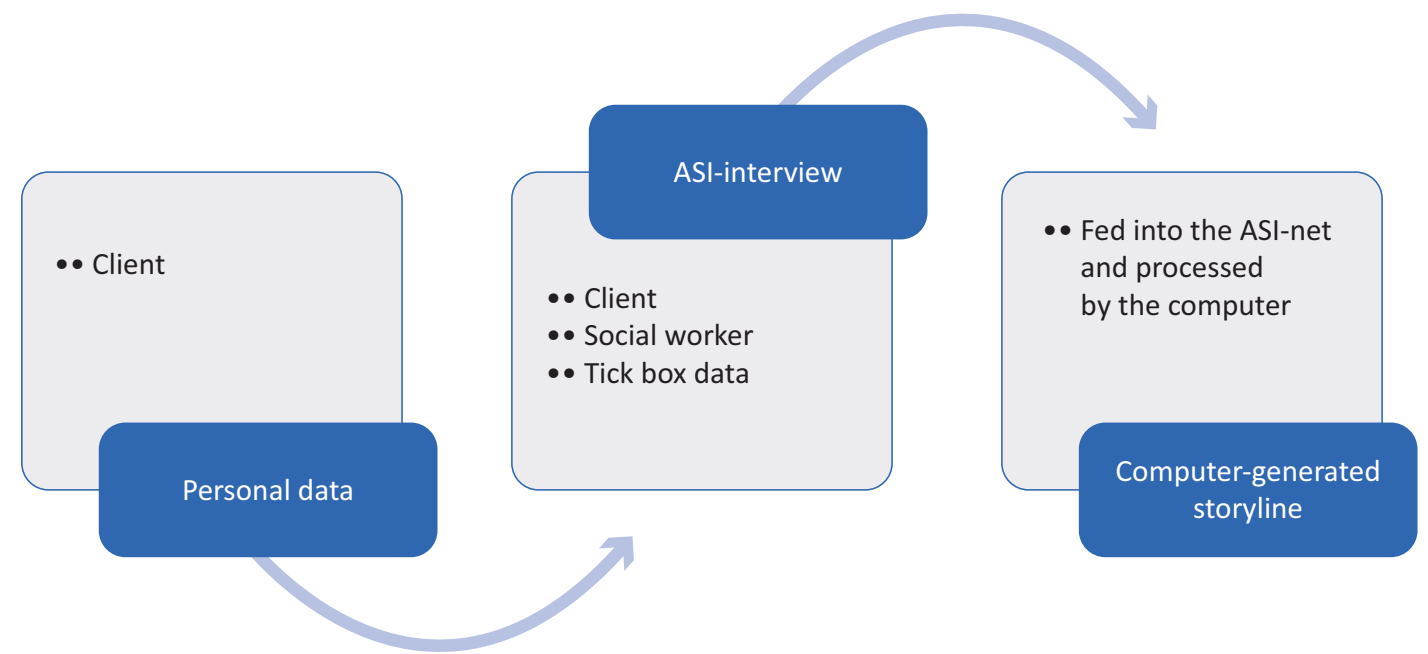

Figure 1. Transformation of the client story into a computer-generated storyline. 
to make the story pass as a human narrative (Jacobsson \& Martinell Barfoed, in press). As this software program is a central part of the ASI data support (as per a telephone interview on December 2018), it is likely that similar strategies are used by social workers using the program. Human editing is needed to soften the bluntness of the computerised storyline.

The example has other interesting dimensions. Aas (2004) found that a database-logic has a strong hold on society today, and that digitalisation and standardisation are parts of this endeavour. Concepts like facts and information change social work discourse. The personal story, with its well-known signs of human narration, for example, hesitations, contradictions, and complexities are reduced to "facts" in a questionnaire. Instead of the clients' stories being produced during social interaction, with the clients' experience and voice as a point of departure, standardised discourse appears reduced and detached (Parton, 2008). The description of the client becomes fact-like, with ambiguities and restrained alternative versions. In this sense, facts are worked up and personal points of view and accounts, which are important for decision-making, run the risk of being left unheard (Martinell Barfoed, 2018). In addition, the results of these kinds of assessment instruments-the figures, scales, and numbers being produced-make the client's life appear fragmented and decontextualised from the complex factors affecting our lives (cf. Peckover et al., 2010). For example, the pre-fabricated questions with set life areas do not take structural circumstances into consideration (Herz, 2012).

People in contact with social services are transformed into data that are assembled in different ways, based on current trends in human service organisations. The individual, like Data-Dennis, is transformed into a virtual data double (Haggerty \& Ericson, 2000), a humanmachine product with a virtual identity. Lash (2002) described how society is increasingly leaving the linear story to focus on facts and information and this may change how meaning is shaped. Aas (2004) claimed that the database as a cultural form differs from the narrative. The database logic affects how identities are established and impacts how knowledge is defined. For example, facts and information in the database are not necessarily linked but can be put together and picked apart for the purpose at hand (also called "data fusion", see Manovich, 2013, pp. 330-340). While the database logic might be the preferred form for policymakers collecting statistics, trying to get a "big picture", narratives from face-to-face interaction appear to be more helpful in individual decision-making (Martinell Barfoed, 2018).

\subsection{Patrick: An Interactional Example}

To demonstrate how the interaction unfolds during a passage in the ASI interview that matches Dennis' storyline, an example is given: Patrick is 25 years old and awaiting trial for growing cannabis. We meet at the probation of- fice, where a male social worker in his 60 s is asking the questions, under the heading "Family and Socializing" in the ASI-questionnaire. The social worker has just asked a rather complicated question about Patrick's marital status, and after a rather long negotiation about how to interpret the question, Patrick summarises:

Patrick: Put 4 [years] and 4 [months].

Social worker: [the pen rasping] Are you satisfied with this situation? You can answer: No, yes, or both.

Patrick: [hesitates] I am satisfied.

Social worker: You are satisfied [looks down and writes in the form].

Patrick: Well, it's not that I wasn't satisfied when I was living together [in an earlier relationship].

Social worker: [looks up] No, but you are not discontent with your present situation? [Patrick shakes his head] No. OK. Well...the questions are a bit tricky at times. Sometimes I don't know how to interpret a question, like in this case. How are you supposed to interpret a certain question? In some cases, you have to reason for what seems to be the most sensible answer.

Patrick: Yes.

Social worker: This is why I sometimes hesitate...like in this case, you see. Because it [the question] is not crystal clear.

The excerpt above demonstrates that the interaction between social worker and client is not straightforward. For example, the social worker's affirmation "You are satisfied", is by Patrick interpreted more like a question: "Are you (really) satisfied?" and Patrick seems obliged to account for his experiences in an earlier relationship. These kinds of affirmations are common in standardised interaction: by repeating the answer, the interviewer reassures that the answer is understood correctly (Houtkoop-Steenstra, 2000). In the last part of the example, the social worker departs from the standardised script and goes "off-track". The complaints from the social worker can be interpreted in different ways: as a way of "softening" and humanising the rather blunt interaction, with its unbalanced power relations, in front of the audience (Patrick and researcher), as well as a way of demonstrating that the interviewer is not a "dope". When making the meta-comments, stepping out of the scripted "on-track" questions (that is, not following the protocol as intended) the social worker uses his discretion (Lipsky, 1980). "Off-track" comments proved to be pervasive in the ASI interviews. In this sense, standardised interaction has conversational qualities (HoutkoopSteenstra, 2000). 
Houtkoop-Steenstra (2000) finds that the questionnaire, to a high degree, is an interactional achievement and that it is situationally accomplished. The interaction between Patrick and the social worker also shows that the standardised interview, to a large extent, unfolds in collaboration. Apart from the power imbalances built into the standardised interview, the social worker and the client both struggle to solve difficulties along the way, be it questions that are difficult to understand or interactional troubles (see Martinell Barfoed, 2018).

By this example of face-to-face interaction, we get a picture of how the interaction preceding Dennis' computerised storyline can unfold. We learn that each part of the ASI-tool has its characteristics, which affect the people-production process, i.e., the final description of an individual client and his or her life situation and possible needs. One missing part in this article is how the social worker enters the binary data into the ASI database. The interaction between the social worker and the computer can shed light on important choices made, affecting the outcome, the digital story. An ethnographic study, shadowing every part of the ASI-chain with "real cases" would give a more thorough picture of the ASI as a digital tool. Still, as a prototype, Data-Dennis is an interesting example of new ways to construct a social work client in the digital era.

\section{Conclusion}

Digital infrastructures, where data can be collected and compared, are embraced by policymakers and state authorities to develop and update the welfare state. However, as Timmermans and Epstein (2010) argue, the consequences of standardisation are not yet fully known, and intended goals often bring along unintended results. Ivarsson Westerberg (2004) provides three explanations as to why these administrative changes have a strong hold on the public sector: (1) the possibility to document (the technical development), (2) government requirements and guidelines to document have bearing on the changes ("the audit society", says Power, 1997), and (3) the will to use these documentation systems, are important factors in their successful implementation. Although human service professions complain about digital documentation taking time from patients and service users, there are benefits that come with the changes. Being on the digital front line, and appearing to get a higher professional status, can make it difficult to be critical to digital innovations and how they fit into social work (cf. Jacobsson \& Martinell Barfoed, 2016).

Data-Dennis, instead of giving a "human impression", rather appears as a "digital dope" (paraphrasing Harold Garfinkel's concept). In the example, personal storytelling is transformed into a digital narrative, where the border between technique and man is blurred and challenged. The right to formulate a personal story in the individual's own words is lost, which make it sound peculiar and de-humanised. When digital classification and stan- dardised assessments are used in professional practices like social work, new questions need to be addressed and answered: How is decision-making affected by the standardised stories entering social work? How is the client represented? Where do the challenges and possibilities lie? More empirical studies are needed to analyse digital era tools.

As discussed in this article, not only the form, but also language is affected by the database logic: the vocabulary itself is influenced by standardisation. In the computer-generated story, an ambiguous discourse was detected. This discourse needed narrative editing to pass as a "meaningful human story". Every language format has linguistic restrictions and narrative discourse is not an exception. For example, personal stories, such as success stories and stories with a happy ending, are often culturally preferred; while others, like narratives of social failure, are less attractive (Hydén, 1995). The examples presented and analysed here demonstrate how a standardised client is produced. The result is a client whose human voice is effaced and represented by the voice of the computer. Without jumping to hasty conclusions, this is a rather remarkable change in a profession where empathy and ethical considerations are paramount (Trevithick, 2012).

Finally, the personal story does not give direct access to an "inner truth" and should by no means be romanticised. However, history shows that "telling your own story" can be as important for the individual as for groups of individuals. Plummer (1995) even regards the telling of personal stories as a human right. In social work, the personal story, in all its messiness and constructiveness, is a given starting point for professional social work. Standardisers of social work need to take this into consideration so that information technology, instead of being "a self-sealing belief system powered by magical thinking" (White et al., 2010, p. 416) is carefully constructed in collaboration with social workers and their clients.

\section{Acknowledgements}

My thanks go to the three reviewers for their careful reading of an earlier draft of this article and for their helpful comments. I am also grateful for the support of colleagues at Lund University, with interest in the standardisation issue.

\section{Conflict of Interests}

The author declares no conflict of interests.

\section{References}

Aas, K. F. (2004). From narrative to database: Technological change and penal culture. Punishment and Society, 6(4), 379-393.

Abramowitz, M., \& Zelnick, J. (2015). Privatization in the human services: Implications for direct practice. Clinical Social Work Journal, 43(3), 283-293. 
Baines, D. (2006). Quantitative Indicators "whose needs are being served?": Quantitative metrics and the reshaping of social services. Studies in Political Economy, 77(1), 195-209.

Berger, P. L., \& Luckmann. T. (1966). The social construction of reality. London: Penguin Books.

Björk, A. (2016). Evidence-based social work behind the scenes. Stockholm: Stockholm University.

Bovens, M., \& Zouridis, S. (2002). From street-level to system-level bureaucracies: How information and communication technology is transforming administrative discretion and constitutional control. Public Administration Review, 62(2), 174-184.

Bowker, G. C., \& Star, S. L. (1999). Sorting things out. Classification and its consequences. Cambridge, MA: MIT Press.

Cicourel, A. V. (1964). Method and measurement in sociology. New York, NY: The Free Press.

Devlieghere, J. (2017). The logic of the database: In search of responsive social work. Ghent: Ghent University.

Garfinkel, H. (1967a). Studies in ethnomethodology. Englewood Cliffs, NJ: Prentice Hall.

Garfinkel, H. (1967b). 'Good' organizational reasons, for 'bad' clinic records. In Studies in ethnomethodology (pp. 189-207). Englewood Cliffs, NJ: Prentice Hall.

Garfinkel, H., \& Sacks, H. (1986). On formal structures of practical action. In H. Garfinkel (Ed.), Ethnomethodological studies of work (pp. 157-198). New York, NY: Routledge \& Kegan.

Gillingham, P. (2011). Computer-based information systems and human service organisations: Emerging problems and future possibilities. Australian Social Work, 64(3), 299-312.

Gillingham, P. (2016). Technology configuring the user: Implications for the redesign of electronic information systems in social work. British Journal of Social Work, 46, 323-338.

Gillingham, P., \& Humphreys, C. (2010). Child protection practitioners and decision-making tools: Observations from the front line. British Journal of Social Work, 40, 2598-2616.

Gubrium, J. F., Buckholdt, D. R., \& Lynott, R. J. (1989). The descriptive tyranny of forms. Perspectives on Social Problems, 1, 195-214.

Haggerty, K. D., \& Ericson, R. V. (2000). The surveillant assemblage. British Journal of Sociology, 51(4), 605-622.

Hall, C. (1997). Social work as narrative. Aldershot: Ashgate.

Hall, P. (2012). Managementbyråkrati. Organisationspolitisk makt i svensk offentlig förvaltning [Management bureauracray: The politics of organizational power in Swedish public administration]. Malmö: Liber $A B$.

Hasenfeld, Y. (1972). People processing organizations: An exchange approach. American Sociological Review, 37, 256-262.
Herz, M. (2012). Från ideal till ideologi. Konstruktioner av kön och etnicitet inom socialtjänsten [From ideal to ideology. Constructions of gender and ethnicity within the social services]. Örebro: Örebro university.

Hjärpe, T. (2017). Measuring social work: Quantity as quality in the social services. Statsvetenskaplig tidskrift, 119(1), 23-46.

Holstein, J. A. (1992). Producing people: Descriptive practice in human service work. Current Research on Occupations and Professions, 7, 23-39.

Holstein, J. A., \& Gubrium, J. F. (2000). The selves we live by. Narrative identity in a postmodern world. Oxford: Oxford University Press.

Hood, C. (1995). The new public management in the 1980s: Variations on a theme. Accounting, Organizations and Society, 20(2), 93-109.

Houtkoop-Steenstra, H. (2000). Interaction and the standardized survey interview. The living questionnaire. Cambridge: Cambridge University Press.

Hydén, L.-C. (1995). Det sociala misslyckandet som berättelse. Att återställa den moraliska ordningen [The social failure as narrative]. Socialvetenskaplig tidskrift, 2(3), 194-207.

Ivarsson Westerberg, A. (2004). Papperspolisen. Den ökande administrationen i moderna organisationer [The paper police. Expanding administration in modern organizations]. Stockholm: Stockholm School of Economics Institute for Research.

Jacobsson, K. (2016). Analyzing documents through fieldwork. In D. Silverman (Ed.), Qualitive research (4th ed., pp. 155-170). London: Sage.

Jacobsson, K., \& Martinell Barfoed, E. (in press). Dokumentation och digitalisering $i$ socialtjänsten [Documentation and digitalisation in the social services]. Lund: Gleerups.

Jacobsson, K. \& Martinell Barfoed, E. (2012). Moving from 'gut feeling' to 'pure facts': Launching the ASI interview as part of in-service training for social workers. Nordic Social Work Research, 2(1), 1-16.

Jacobsson, K., \& Martinell Barfoed, E. (2016). Trender i socialt arbete [Trends in social work]. In A. Meeuwisse, H. Swärd, S. Sunesson, \& M. Knutagård (Eds.), Socialt arbete: En grundbok [Social work: A basic book] (pp. 313-330). Stockholm: Natur \& Kultur.

Lampland, M., \& Star, S. L. (2009). Reckoning with standards. In M. Lampland \& S. L. Star (Eds.), Standards and their stories. How quantifying, classifying, and formalizing practices shape everyday life (pp. 3-31). Ithaca, NY: Cornell University Press.

Lash, S. (2002). Critique of information. London: Sage.

Lauri, M. (2016). Narratives of governing: Rationalization, responsibility and resistance in social work. Umeå: Department of Political Science \& Umeå Centre for Gender Studies.

Lipsky, M. (1980). Street-level bureaucracy. New York, NY: Russell Sage Foundation.

Lundgren, L. M., Armelius B.-Å., Armelius, K., Brännström, J., Chassle, D., \& Sullivan, L. (2012). Beskrivning av 
tre klientprofiler inom svensk missbruksvård [Descriptions of three client profiles in individuals assessed for a substance disorder in the Swedish social welfare system]. Socialvetenskaplig tidskrift, 19(3/4), 200-216.

Mäkitalo, Å., \& Säljö, R. (2002). Invisible people: Institutional reasoning and reflexivity in the production of services and "social facts" in public employment agencies. Mind, Culture, and Activity, 9(3), 160-217.

Manovich, L. (2013). Software takes command. New York, NY: Bloomsbury Academic.

Martinell Barfoed, E. (2018). From stories to standardised interaction: Changing conversational formats in social work. Nordic Social Work Research, 8(1), 35-49.

Maynard, D. W., \& Schaeffer, N. C. (2006). Standardization-in-interaction: The survey interview. In P. Drew, G. Raymond, \& D. Weinberg (Eds.), Talk and interaction in social research methods (pp. 9-27). London: Sage.

McLean, C.M \& Hoskin, K. (1998). Organizing madness: Reflections on the forms of the form. Organization, 5(4), 519-541.

McLellan, T., Cacciola, J. C., Alterman, A. I., Rikoon, S. H., \& Carise, D. (2006). The addiction severity index at 25: Origins, contributions and transitions. American Journal on Addictions, 14, 113-124.

Munro, E. (2005). What tools do we need to improve identification of child abuse? Child Abuse Review, 14(6), 374-388.

National Board of Health and Welfare. (2014). ASImanualen: Anvisningar till ASI Grund och ASI Uppföljning [The ASI-manual: Instructions to ASI basic and ASI follow-up]. Stockholm: National Board of Health and Welfare.

National Board of Health and Welfare. (2018). Metodguiden för socialt arbete [A methods guide for social work]. Socialstyrelsen. Retrieved from www.socialstyrelsen.se

Parton, N. (2008). Changes in the form of knowledge in social work: From the 'social' to the 'informational'? British Journal of Social Work, 38(2), 253-269.

Peckover, S, White, S., \& Hall, C. (2010). Making and managing electronic children: E-assessment in child welfare. Information, Communication and Society, 11(3), 375-394.

Plummer, K. (1995). Telling sexual stories. New York, NY: Routledge.

Ponnert, L. (2015). Utredningsarbete $i$ den sociala barnavården [Investigation work in Swedish child care]. Malmö: Gleerups.

Potter, J. (1997). Representing reality. Discourse, rhetoric and social construction (2nd ed.). London: Sage.

Prottas, J. M. (1979). People-processing. The street-level bureaucrat in public service bureaucraties. Lexington: Lexington Books.
Power, M. (1997). The audit society. Rituals of verification. Oxford: Oxford University Press.

Prior, L. (2003). Using documents in social research. London: Sage.

Rogowski, S. (2011). Managers, managerialism and social work with children and families: The deformation of a profession? Practice Social Work in Action, 23(3), 157-167.

Rose, N. (1991). Governing by numbers: Figuring out democracy. Accounting, Organizations and Society, 16(7), 673-692.

Sackett, D. L., William, M.C., Rosenberg, J. A., Muir Gray, R., Haynes, B., \& Scott Richardson, W. (1996). Evidence-based medicine: What it is and what it isn't. British Medical Journal, 312(January), 71-72.

SALAR. (2019). Digitalisering inom social omsorg [Digitalisation in social care]. The Swedish Association of Local Authorities and Regions. Retrieved from www.skl.se

Skillmark, M. (2018). Mission standardization: The implementation and execution of manual-based assessment tools in social services (Unpublished Doctoral dissertation). Växjö: Linnaeus University.

Smith, D. (1974). The social construction of documentary reality. Sociological Inquiry, 44(4), 257-268.

Suchman, L., \& Jordan, B. (1990). Interactional troubles in face-to-face survey interviews. Journal of the American Statistical Association, 85, 232-241.

Svensson, L., \& Larsson, S. (2017). Digitalisering och socialt arbete-En kunskapsöversikt [Digitalization and social work: A literature review]. Landskrona: Lunds universitets internetinstitut (LUii).

Timmermans, S., \& Epstein, S. (2010). A world of standards but not a standard world: Toward a sociology of standards and standardization. Annual Review of Sociology, 36, 69-89.

Trevithick, P. (2012). Social work skills and knowledge (3rd ed). Maidenhead: Open University Press.

White, S., Hall, C., \& Peckover, S. (2009). The descriptive tyranny of the common assessment framework: Technologies of categorisation and professional practice in child welfare. British Journal of Social Work, 39(7), 1197-1217.

White, S., Wastell, D., Broadhurst, K., \& Hall, C. (2010). When policy o'erleaps itself: The 'tragic tale' of the Integrated Children's System. Critical Social Policy, 30(3), 405-429.

WHO. (2001). International classification of functioning, disability and health. Geneva: World Health Organization.

Zimmerman, D. H. (2016). Record-keeping and the intake process in a public welfare agency. In S. Wheeler (Ed.), On record. Files and dossiers in American life (2nd ed., pp. 289-321). New Brunswick: Transaction Publishers. 


\section{About the Author}

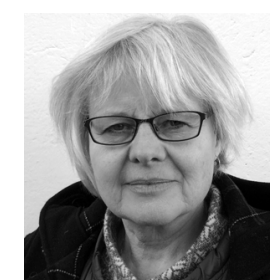

Elizabeth Martinell Barfoed is a Lecturer at the School of Social Work, Lund University, Sweden. With a degree in Social Work, earned in the 1970s, and another in Journalism, earned in the 1980s, social work has been the center of her research, first in practice, then in academic settings. In November 2008, she defended her PhD dissertation Adoption Stories, a constructionist and narrative study, at Lund University. Her later work explores standardisation and digitalisation and the consequences for social work, resulting in several Swedish and international publications. 